\title{
Diplomacy of International Crises Management: Kuwait Foreign Policy as a Model (A Survey Study)
}

\author{
Meshal Ahmed Al Mansour ${ }^{1}$ \\ ${ }^{1}$ Faculty of Economics and Political Science, Cairo University, Cairo, Egypt \\ Correspondence: Meshal Ahmed Al Mansour. E-mail: almansourmeshal29@gmail.com
}

Received: July 19, 2020

Accepted: August 31, 2020

Online Published: September 24, 2020

doi:10.5539/ass.v16n10p34

URL: https://doi.org/10.5539/ass.v16n10p34

\begin{abstract}
The importance of the study of crisis management diplomacy stems from the fact that it is a tool to prevent and avoid all confrontations and its disastrous consequences. In particular, regional and international issues and crisis has become complex and multiple. In addition, the units of both regional and international environments have been increased. These developments further complicated the phenomenon of making and implementing foreign policy according to the mechanism of crises management diplomacy. As a result, making and implementing foreign policy in its traditional official framework has become insufficient to understand the nature of international relations. Rather, it has to be expanded outside of this framework to understand the role of crises management diplomacy in making foreign policy. Therefore, there have been some attempts to provide academic scientific frameworks to explain the process of making and implementing foreign policy according to the variables of this development. The study has monitored this matter and concluded that foreign policy, diplomacy and crises management diplomacy have significantly evolved from a simple and traditional phenomenon related to the issue of security and formal promotion of relations to multidimensional phenomenon closely related to the various economic, political, social and cultural areas of societies. This technique has been based on traditional methods such as negotiations. In recent decades, it has adopted accurate and effective technical methods. These methods include political methods such as good offices, mediation and compromise. Also, there are legal methods such as international arbitration and the presentation of disputes to international and regional organizations. There are also deterrent ones such as economic embargo, boycotting and freezing funds. It means that developed countries control over international relations, and developing countries participate effectively in order to preserve the rights of nations and interact fruitfully through dialogue and peaceful coexistence.
\end{abstract}

Keywords: diplomacy, crises management, Kuwait, international crises, crises

\section{Theoretical Framework}

\subsection{Introduction}

The post-Cold War period witnessed frequent crises and conflicts, the most prominent of which were the Second Gulf War and the increase of ethnic and tribal conflicts, as well as internal conflicts resulting from the growing demand for justice and democratic change, and respect for human rights. The Security Council tried during that period to activate its role in maintaining international peace and security at the international level. The diplomatic tool has been used in the management of international crises. Previously, this tool was limited to other areas for long time. The diplomacy of crises management is used as a tool to avoid all confrontations, especially the military ones and its damages. Also, the importance of this diplomacy increased to achieve the welfare of societies and peoples.

Accordingly, many studies have released. They provided academic scientific frameworks to explain the process of making and implementing foreign policy according to the variables of this development. These studies are embodied in scientific research and studies, which try to provide an explanation for the process of crises management by using the mechanisms and tools of foreign policy in policy-making and implementing. The current study is a survey of the trends of diplomacy of international crises management. In this vein, the study is divided into five axes. The first deals with the concepts of the study. The second addresses the diplomacy of management crises. The third explores the management of international crises. The fourth examines foreign policy, diplomacy and crises management. The fifth scrutinizes Kuwait's foreign policy and its association with crisis management in general. 


\subsection{Study Concepts}

The study is based on a set of concepts, namely diplomacy, crisis and crisis management diplomacy. The study in the next section will address briefly these concepts.

\subsubsection{Diplomacy}

Diplomacy is defined as the process of communication and negotiation in the area of global politics (Bellis \& Smith, 2004, pp. 545-547). It is a tool used in the process of negotiation and representation among states with the aim of managing and settling international relations by diplomats and ambassadors. It is also a concept linked to foreign policy because it is the art of negotiations management between countries in the process of implementing foreign policy (Smeitz, 2012, pp. 23-26). Diplomacy is also a controversial term used in the study of global policy. It can have various meanings, depending on user and usage. It is an important political tool used by international actors (Nye, 2004, pp. 255-262). Diplomacy is also defined as a political process used by a state to achieve the objectives of its foreign policy and to manage its relations with other states and other international actors with whom they have different relations (Mikled, 2013, p. 153).

\subsubsection{Crisis}

Crisis is defined as an unexpected event that causes dire consequences to a state, institutions, property and souls. It is confronted in the shadow of limited time and few capabilities (Selim, 1988, pp. 78-79). It is a critical and decisive moment concerning the destiny of a state and its institutions. Given the difficulty of this problem, decision makers are unable to think clearly or to understand what is happening (Frankel, 1976, pp. 85-88). It is defined as an international phenomenon occurring within the framework of the international system as a result of interactions between its units. It involves potential threats to international relations (Herman, 1969, pp. 404-410). It is also defined as a surprise which carries a threat to goals, values and beliefs. It is a state of imbalance that results in various, multi-dimensional, and internal and external disturbances. The extension of the crisis leads to the occurrence of crisis beyond the regional border to become an international crisis (Alawi, 1987, pp. 159-160).

\subsubsection{Diplomacy of Crisis Management}

Diplomacy of crises management means foreign relations. It is a synonym for foreign policy. In other words, it is the political method of implementing foreign policy (Selim, 2002, pp. 19-22). It means how to deal with the crisis to reach the best possible results. It is also a series of measures and decisions aimed at controlling the crisis and reducing its aggravation in order to lead to the outbreak of war. Put differently, it means dealing with the elements of crisis by using a combination of bargaining tools to achieve the objectives of the state and preserve its national interests (Snylor, 1972, pp. 212-217). It is also the work aimed at bringing about reconciliation between hostile parties through peaceful means. According to chapter VI of the Charter of the United Nations, these peaceful means are: negotiations, troop's deployment, mediation, investigation and facts finding (Huwaidi, 1993, pp. 177-178). Crisis management diplomacy is all actions and decisions that lead to controlling and reducing conflicts in the face of attempts of provocation and escalation (Mukhtar, 1992, pp. 283-284). Crises management diplomacy is a future management that anticipates and sets possibilities for what might happen. This may be rejected by some leaders and decision-makers who start working with excessive optimism. It is the art of managing control by raising the efficiency and capacity of decision-making system to overcome the elements of heavy bureaucratic mechanism that may be unable to cope with successive and surprising events and may be unable to remove the state from the status of relaxation and flabbiness (Snyder, 1976, pp. 680-682).

\section{Diplomacy of International Crises Management}

Brzeziniski's Study was a response to crises and challenges facing the United States where it became the only superpower after the collapse of the Soviet Union. The author stresses that the role of the United States will continue to be necessary in the coming years. It is necessary for the US, with the continued change in the distribution of global powers, to succeed. Strategically and culturally, it is better to study and examine its relationship with the new East. Thus, the US can form the geopolitical orientation of a developed world, in which power is shifting from the West to the East. The author also points out that the world needs the United States, which characterized by vital economy, attractive social appearance, international respect, strategic carefulness (Brazeziniski, 2012).

According to (Hocking \& Melissen, 2015), there is a debate among scholars of international relations and information technology about the initial implications of diplomacy in the digital age. The report also deals with diplomacy, digital diplomacy and crises management diplomacy. The report points out that the first decade of the $21^{\text {st }}$ century witnessed the emergence of crises management diplomacy and digital public diplomacy which means the use of the Internet and modern communication technology to communicate with audience and to 
create the environment of empowerment of a country's foreign policy. Nowadays, it is possible to communicate immediately with Internet communities, which constitute a growing political force in the process of foreign-policy making. Therefore, states seek to integrate public diplomacy with crises management diplomacy and the digital diplomacy into the process of foreign policy decision-making (Hocking \& Melissen, 2015).

While Emara's study aims at identifying the role of the Palestinian diplomacy in managing the health crisis during the siege of Gaza governorates in the period from 2006 to 2013. The study deals with the nature of the health crisis, the reality of Palestinian diplomacy, the function of the Palestinian diplomatic mission, the health crisis facing the health sector, the role of the government in Gaza in managing the health crisis, and the effectiveness of popular diplomacy as an alternative to the role of official diplomacy (Emara, 2014).

There is a study of Abu Arshid, which shows that the contemporary Ukrainian crisis represents the biggest and most serious challenge faced by US President Barack Obama at the level of US foreign policy. The study concludes that the US faces a dilemma about whether to intervene in the Ukrainian issue or not. If the United States turned a blind eye to the Russian intervention in eastern Ukraine and Crimea without a response, the credibility of the United States would undermine. In particular, the United States' allies rely on its protectionist umbrella and have great credibility in the US. The US administration was facing a credibility crisis. This credibility has been eroding due to Obama's hesitated policies. However, if the United States decided to respond, it would face great clashes.

Sulaiman's study shows that the structure of the international system affects the management of its units of international crises. It affects the tools and results of such management. The international system itself is also affected by the method of international crises management, especially by the superpowers. Small or profound changes in international system can be occurred. In fact, a full transformation can be occurred in it to take another form of international polarity through three variables which are international biases, international conflict arena and international values. The study concludes that the existing development in the international system explain the transformation of limited conflicts into severe ones, thus accelerating the emergence of many crises. The study of the international system also helps to understand why war is still possible and why resolving crises are more difficult under a particular international system. In addition, the recurrence of international crises under a particular international system refers to the anarchic nature of inter-states policies in this system. Since there is no central authority to control the conduct of a large number of independent political units, the conflict of interests between these units continues (Suliman, 2011).

According to (Ameen, 2010), the crisis of occupation of Iraq is an entry to crisis of occupation of Iraq is an entry to study how the United States, as a major power in the international system, can affect the United Nations on the one hand and the ability of the Arab system, to which Iraq belongs, to survive as a distinct regional system on the other. The study examines the implications of the crisis of occupation of Iraq on the Arab system where the US sought to adopt and implement particular policies. It challenged the resolutions of the United Nations and adapted them to serve its interests (Ameen, 2014).

Ahmed's study interests in examining the variables that have affected the international crisis during the past decade and focuses on the study of the international crisis in the future. The study identifies these variables in several important points, which are: unilateralism in decision-making in the international crisis, the continuation of unilateral polarity, the rise of pax-Americana, transformation intended to the transfer of the crisis to another area or time, the type of political system, the rise of international terrorism, the increasing crises of conflict, the steady rise ethnic and racial conflicts, the continued importance of geographic location, the increasing role of the third party, exceeding international legitimacy and shifting to de facto policies (Ahmed, 2005).

According to (Zaharna, 2003), public diplomacy and crises diplomacy are important tools in the arsenal of American smart power. However, smart public policy in its dealing with crises diplomacy requires a sound understanding of credibility, self-criticism and the role of civil society in creating soft power. If public diplomacy falls to the level of propaganda, it will not only fail to persuade, but may also undermine soft power. Therefore, public diplomacy must be based on a two-way process where soft power depends primarily on understanding the minds of others and their own concepts. The study concludes that public diplomacy and crises one are the soft face of US foreign policy relations. They retreated due to the requirements of the Cold War, but they regained their strength after the end of war.

In sum, it can be said that all studies dealt with the diplomacy of international crises management introduces multidimensional contribution. Some analysts indicate that the US became the great power after the collapse of Soviet Union. Therefore, the world is in dire need of the involvement of the US in international issues and crises. This is due to the fact that the US is characterized by international responsibility and respect for international law. 
In addition, it has cultural, economic and political capabilities, and international experiences which made the US able to confront many crises. If the US did not intervene in these crises, they would turn into violent wars. Developments in the international system also explain the way in which limited conflicts are transformed into intense ones. Consequently, many crises continue to accelerate in which war options remain possible.

Other analysts believe that the structure of international system makes the resolve of crises more difficult in the light of the recurrence of international crises. This indicates that the current international system fuels the anarchic nature of states' policies in this system. Since there is no central authority follows clear criteria in the management of international crises to control the conduct of international units, the conflict between these units continues. In particular, the management of great powers is different according to the degree of interest and benefit.

In sum, the US relied in the management of international crises on the exploitation of international legitimacy through the resolutions of the United Nations to intervene in these crises militarily and peacefully. Furthermore, the US exploits the political, economic and military capabilities offered by regional organizations such as the North Atlantic Treaty Organization (NATO), International Monetary Fund (IMF), the World Bank, World Trade Organization, and the Group Seven, which Russia joined it as observer. In particular, the US established itself as a sponsor of world peace and announced that ensuring national security is a protection of global security. However, the US, in many cases, intervenes individually and bears the consequences of this intervention, and justifies it later. In order to consolidate its leadership and hegemony and to confront all matters that might hinder this hegemony, the US sometimes resorts to fabricating crises to settle its accounts with some regimes. It runs this scenario tightly and accurately to produce international and regional positions which are in line with their strategic interests.

\section{International Crises Management}

Clayton's study indicates that the crisis of global oil price is a major international crisis. The study monitors concerns about the collapse of global oil prices, the crisis of oil depletion and volatility of its price. It shows that concerns about depletion of the oil supplier at the global level are incorrect. It also stresses that technological developments and geopolitical shifts led to a sharp drop in prices such as the current decline. The market of oil derivatives witnessed a rapid expansion. In addition, the percentage of $76 \%$ of Americans in 2008 believed that the oil supplier was running out of the global market. There more also concerns about the climax of oil. Therefore, some analysts-before the recent collapse in prices-believed that the price of crude oil may remain close to $\$ 100$ to $\$ 150$ a barrel.

According to (Al-Tammer, 2015), the US has motivations and policies that outline the US behavior towards the Middle East. The study deals with four models of contemporary international crises, which are Iran, Iraq, Syria and Lebanon. The study shows how the two George W. Bush and Barack Obama administrations dealt with these crises. These cases are highly intertwined and overlapping as a result of the existing cultural and political environment in the region. The study finds that the Bush administration was dominated by the logic of ideological fanaticism based on using force in managing the Iraq crises, and ignoring the United Nations and the international community. The Bush administration supported Syria's opponents in Lebanon and used international resolutions to pressure Syria. While the Obama administration did not make a fundamental change in addressing the crises of the region. It retained many elements of the Republican Party in dealing with crises. However, it added new tools where it tried to mobilize the international community to form a public opinion supporting US decisions and reduced the language of using the military force to manage these crises.

Abdul Kader's study discusses a main hypothesis that the United States dealt with the crises of nuclear proliferation issues not on the grounds that such crises negatively affect the global system, but on the grounds that these crises threaten the interests of the US and its allies despite the fact that the policies of the US in this regard undermine the foundations of global system and its credibility.

Kupchan's study extensively scrutinizes the cases of historical international crises, whether or not these cases succeed in achieving a stable peace. The study provides a diplomatic roadmap through which crises are managed and enemies are turned into friends. In addition, the study examines a set of traditional sayings, or so-called common myths, about the possible causes of peace. For example, the study explores the theory of democratic peace based on a main hypothesis that democracies do not fight each other. Therefore, the spread of peace in the world depends on the increase of democratic states. The study is based on several pillars for managing the international crisis and achieving peace, in addition to skilled diplomacy. These pillars are: 1) dialogue with enemies which is not a kind of appeasement, but a kind of diplomacy. Hostility between countries does not end through isolation and containment, but on the contrary through negotiations and the settlement of differences. 2) 
Democracy is not a precondition for achieving a stable peace. Autocratic states, in turn, are capable of establishing lasting partnership with each other and with other democratic states. For example, the United States should build its external relations according to the behavior of other countries' foreign policies, not according to the nature of their policies (Kupchan, 2010).

Al-Beheiry's study revolves around the vital role of negotiation in managing international crises. Such negotiations prevent the use of force by one party against another. The study also deals with the extent of success of negotiations between Iran, the European Troika and the United States in managing this crisis. In particular, there is a great conflict between the three parties on the nature of the crisis. The US imposed economic sanctions and did not resort to using the military solution. The peaceful means of international crises are characterized by multiplicity and change. Additionally, international law tended to prevent wars and resolve international crises conflicts peacefully. This is consistent with the provision of the Charter of the United Nations in Article 2/3 and $3 / 3$. Article $2 / 4$ prohibits the use of force or threat to use it as a means of resolving international disputes (Al-Beheiry, 2009).

Based on the aforesaid literature, it can be said that all previous studies of international crises management have made a set of contributions. Previous studies chronicled international crises and their causes and parties, and the way in which the parties of the crisis and the regional and international forces dealt with. They monitored situations in which crises are prevented from aggravation and monitored also failed interventions, with providing thoughtful theoretical framework and interpretation of both cases. This resulted in a number of theories that are fundamental to the management of the international crises and the achievement of peace. The whole theoretical contributions to the management of international crises is based on the idea of skilled diplomacy and global peace, whereby enemies are transformed into friends through dialogue with enemies, the settlement of disputes and establishing partnerships with all parties. It should be noted that the studies of international crises crystallized during the 1960s. There have been successive efforts to formulate a conceptual framework and a set of hypotheses that can be applied to the analysis of various international crises management situations. In this context, there are various theoretical attempts. For example, the study of Charles Hermann \& Linda Brady followed the numbers of 311 cases of international crises which has been enumerated in the history of international relations until then. Also, one of the most notable efforts in this context was the study of Michael Brecher, Jonathan Wilkenfeld and Sheila Moser, who compiled information on 278 international crises that the world witnessed during the period from 1929 to 1979. The study concludes that international crises or foreign policy crises arise from a change in the internal or external environment of a state in a way that is seen by the highest decision maker of foreign policy as a threat to important values of the state. Besides, decision-makers also recognizes the limited time available to deal with such threats (Nazir, 2010). Although there are various studies of management crises and many important schools of the analysis and study of foreign policy, the approach of crises management remains extremely impressive. In particular, this approach reveals the pros and cons of processes of foreign policy management. This makes this approach important to decision-makers, who concerned with improving the performance of foreign policy-making institutions.

\section{Relationship Between Foreign Policy, Diplomacy and Crises Management}

According to (Moos, 2012), the new economic diplomacy, which is called soft power by Anglo-Saxons, contributes significantly to the resolution and management of international crises. It has grown in parallel with the accelerated paces of globalization of economy. It can also be said that it is the result of the growing global spread of companies, the growing importance of globalization and its role in production processes, and the spread of new communication technologies. Moon's study illustrates that the consolidation of good economic diplomacy can turn into crises management diplomacy, and then become a strong source in the success of traditional diplomacy and the political project, which remains at the center of diplomatic activity.

Klavins' study shows that the old diplomacy was characterized by comprehensive perception. It was also unorganized, unstable and geographically limited due to poor means of communication. In contrast, modern diplomacy is characterized by the fact that it no longer reflects the personal wishes of presidents or kings, but governments became responsible for such activity before parliament. The study also shows that modern diplomacy and crisis management diplomacy is one of the mechanisms of the implementation of foreign policy. It is part of international relations determined by an organizational structure which is international law. The primacy of all over the part makes international law the one under which diplomatic law is found. International law is the organizational structure under which foreign relations of states are determined, based on a set of legal principles directed to organize foreign relations of political units and other international actors. While crises management diplomacy is the modern method of managing foreign affairs of various international actors (Klavins, 2011). 
According to (Matwiezak, 2010), the global environment has become unfavorable for the United States to achieve its vital interests as a consequence of international public opinion dissatisfaction with the US policies. These policies are contrary to United States' deeply rooted values such as democracy, good governance, respect for human rights, pluralism, respect for others, and managing and addressing international crises. Matwiezak's report shows that US public diplomacy has lost a great deal of its flexibility due to the multiplicity of its institutions. In addition, the efforts of these institutions are conflicting. Simultaneously, funding US public diplomacy activities has declined to reach about $\$ 1.5$ billion in 2009 compared with the US defense budget which amounted to about $\$ 717.6$ billion in the same year.

Fawzi's study shows that the events of September11, 2001 restored the momentum to public diplomacy as a tool to achieve the goals of US foreign policy. Since the end of the Cold War, there was a false belief, lasted for a decade, that there was no need for public diplomacy. In particular, the United States succeeded in eliminating communism. Then, the international system became a unipolar system. These events have also proved that public diplomacy must be a long-term tool. It must be developed to include all kinds of diplomacy in its new form to deal with the requirements of the present era. In particular, the events of September 11 proved that Anti-American sentiment can have serious consequences for US interests at home and abroad (Fawzi, 2010).

Al-Batool's study focused on the analysis of Yemeni diplomacy in the United Nations with a case study of the voting behavior in the General Assembly towards a set of crises, and national and international issues, compared to some effective countries in the regional system such as Syria, Saudi Arabia and Egypt and effective international powers in the international system such as the United States, Russia and France during the period of study (1990-2003). The study also deals with the Yemeni voting behavior in the Security Council during the Second Gulf Crisis (1990-1991). The study concludes that Yemen's foreign policy was characterized by continuous activity, especially after re-unification of Yemen on May 22, 1990, with the aim of achieving distinguished Yemeni diplomacy at the two regional and international levels (Al-Batoul, 2009).

A study of Al-Hajj shows that the Palestinian diplomatic experience is unique and has its specificity derived from the specificity of the Palestinian cause. Therefore, it is distinct from the other traditional revolutionary diplomas of the rest of countries. Due to the occupation of the Palestinian land, the absence of the Palestinian people and the attempts of the obliteration of Palestinian identity, Palestinian diplomacy forced to focus on the Palestinian entity by highlighting the national character of Palestinian people and perpetuating the militant identity (Al-Hajj, 2007).

According to (Abdel Wahab, 2003), the Second Gulf crisis has caused fundamental changes in Egypt's relations with the main parties of the crisis, the United States, Iraq and the GCC countries. The relationship between Egypt and Iraq grew worse. At the level of official diplomacy, relations between two parties have been severed. The study finds that the period of severing relations between the two parties, which followed the Egyptian-Israelipeace treaty in the 1980 s of $20^{\text {th }}$ century, did not prevent both from the strategic security communication. This has been crystalized in Egypt's effective role in supporting Iraq during its war against Iran (Abdel Wahab, 2003).

Heijala's study sought to analyze contemporary diplomacy and the forms of international communication of the superpowers under the new international system during the period from 1990 to 1996. It explained that the countries of the north and the elite of the south are benefiting from diplomacy and means of international communication. Furthermore, the study shows that the world of the south suffers from most of the conflicts of the world and international problems (Heijala, 2000).

Accordingly, all studies dealt with the relationship between foreign policy, diplomacy and international crises management have made a multi-level scientific contribution. The academic efforts focused on many of the diplomatic concepts and their types, and recent concepts in this regard. The previous academic studies compared between the traditional and modern mechanisms of the practice of diplomacy. In addition, they observed global environment debates as a promoter of global peace and security or as an incentive for conflict and refereed to some diplomatic images and cases which are subject to certain specificities. Previous studies are characterized by exaggeration in the successes of diplomatic tool in many crises. However, these studies are still theoretical efforts accompanied by some ideological orientations and political and national biases. In fact, despite the inevitability of following diplomatic tools in the face of international crises, there is a growing trend to use the hard power in foreign policy more than ever before. Thus, several points may be monitored as follows:

- The events of September 11, 2001 were an obstacle to diplomatic work. These events led to the confusion of the international community and the acceptance of concepts of power in international politics and the exclusion of the concepts of diplomatic work. 
- When we look closely at the international crises of the two past and present centuries, we find that sovereign states intervene in the internal affairs of small countries. Therefore the world is more vulnerable to wars and the use of power than of politics.

- The weakness of international competition and the imbalance of the world powers between effective international actors such as the European Union, Russia and China in the face of the United States have had a negative impact on the diplomatic management of the international crises. This was obvious in many situations and crises which led to the use solid power.

- All current conflicts are characterized by the failure of states to accept diplomatic tracks and to move according to the international norms to achieve international peace and security, although the diplomatic options and international norms were successful in achieving satisfactory results in many international issues and crises.

- The marginalization of the role of international institutions concerned with resolving disputes and international issues through peaceful and diplomatic means. For example, the United Nations has been turned into ineffective institution. It has often been used to pass individual and unilateral decisions in many international situations such as the war on Iraq (Al-Futtaisi, 2018).

- There is no room for soft diplomacy to play its natural role as a basis for political action. Instead, states resorted to power as an alternative to diplomacy. As a result, serious problems have been occurred such as terrorism, violence and chaos.

\section{Kuwait's Foreign Policy and Its Relationship to Crises Management in General}

Al-Motaiiri \& Zaki's study shows that Kuwait is in dire need of shifting from preventive diplomacy to economic diplomacy and crises management diplomacy in order to maximize benefits and increase the margin of political maneuver and establish economic alliances. Kuwaiti officials also explained that the multiple benefits of globalization are the direct overlap and mutual influence between politics and economy in the new world order. The reform of the international financial system has become directly related to the issue of terrorism where the US completely refused to disclose the secrecy of bank accounts before the events of September 11. Subsequently, it called for the abolition of such secrecy after 11 September (Al-Motairi \& Zaki, 2013).

According to (Al-Mansour, 2013), the economic tool has recently played a key diplomatic role in states' foreign policy. In particular, the military tool, as one of the most important tools of foreign policy, had declined. The economic tool became the most effective tool in international relations despite its negative and positive aspects. The negative aspect is the economic sanctions, while the positive one is economic assistance and incentives, which has become a large part of the diplomatic work and foreign policy for great powers.

Khalidi's study illustrates that Kuwait has dedicated a particular attention to human rights at the internal level and quiet diplomacy at the external level since the end of Iraqi invasion. Kuwait believed that invasion was related to developments occurred in human rights at the international level. Kuwait turned its attention to human rights and supported the diplomatic activity in international forums. It has not hesitated to sign and ratify a large number of international and domestic conventions and legislations guaranteeing human rights (Al-Khalidi, 2012).

Bahgat's study concluded that Kuwaiti Fund for Arab Economic Development implemented various policies, projects and programs to support Arab issues in the political economic, social, security and developments fields. In this vein, the study pointed out that Kuwait hosted the first Arab economic summit and many Arab activities, notably the special meetings on the Palestinian issue (Bahgat, 2011).

The study of Al-Muzayn aims at reaching an objective judgment on the research problem, which was the regional countries of Kuwait (Iraq-Iran-Saudi Arabia), and the international influences represented by the US strategy in the Middle East and its repercussions on Kuwait's national security in the post-Cold War phase.

Pollock's study indicates that the US, for the liberation of Kuwait, sent 500.000 of its troops, along with 200.000 of other troops from 33 other countries. This war, called Desert Storm (January 16 to February 27, 1991), resulted in killing 148 US soldiers and about 137 non-combatant deaths, as well as 458 were wounded. The 1991 Gulf War reduced Iraq's conventional weapons capabilities by about half. However, before the so-called war of liberation of Iraq in March 2003, Iraq was still superior in ground troops to Iran and the Gulf countries (Pollock, 2007).

According to (Al-Azmi, 2014), Iraq's invasion of Kuwait was a crisis and a great challenge to Kuwait in particular and the GCC countries in general. The invasion surprised these countries and posed an unprecedented 
security threat to the Gulf countries. This did not prevent the Gulf from the construction a Unified Gulf Position, as well as the collective political movement to manage the crisis of invasion. The GCC mobilized its sources of power to confront the sources of threat where the GCC was the most stable regional system. Kuwait achieved many of its objectives that are in line with the state's public policy economically, strategically and politically.

The study of Amiri \& Soltani shows that the Gulf region witnessed a series of crises and transformations in the 1990 s of the $20^{\text {th }}$ century. Such crises impacted on the course of world political life, and on the political orientations of the United States and the great powers at that time, and also on the GCC countries. The most important of these transformations is the collapse of the Soviet Union. This event finalized the old global system based on bipolarity, which allowed the US to become the world's main force in the international system. In the midst of these developments, the Gulf crisis came after the Iraqi invasion of Kuwait (Amiri \& Soltani, 2011).

Alkenaee's study shows that despite the liberation of Kuwait and the withdrawal of Iraqi forces, the Iraqi invasion of Kuwait remained in mind. It was a shock to the Gulf, Arab and even regional thought. Consequently, the concepts and constants of the GCC countries have been shaken. In particular, after the US introduced the concept of American imperialism to the region (Alkenaee, 2011).

Al-Bashir's study illustrates that Kuwaiti Foreign Ministry and diplomats played an active and influential role in many conflicts at the two regional and international levels. The most important of these efforts was in many conflicts such as the Arab-Israeli conflict. In addition, diplomacy played a key role after and during the Iraqi occupation of Kuwait by defending the rights of Kuwait and presenting the case to international and regional organizations until the state restored its full sovereignty over its territory.

According to (Al-Naqi, 2010), small states always seeks to protect their national security and secure their regional environment from threats through diversification of partners, expansion of alternatives system, raising new issues in the international system, and expansion of diplomatic activity and foreign policy movement based on all kinds of diplomatic means. Kuwait is one of the smallest countries in the international system. However, it is characterized by quite diplomacy. Kuwait has great economic capabilities. Therefore, it has a great influence at the two international and regional levels despite its limited military and defensive capabilities.

Accordingly, all studies dealt with the diplomacy of international crises management in Kuwait's foreign policy monitored and presented a number of indicators that refer to the development of Kuwaiti diplomacy from its inception until now. Kuwait has a great deal of experience in ending crises, making it a destination for the conflicting parties and an active player in the region. It has its own vision based on understanding the threads of international politics and taking into consideration the strategic interests of the international and regional powers in the region. Practically, the Kuwaiti foreign policy is based on a clear vision before taking decisions related to foreign policy in all circles of political and diplomatic activities. Kuwait created a place on the scene of events and issues in the region by devoting the logic of good relations, neglecting the slogans of boycott and mutual accusations. Kuwaiti's foreign political activity is also based on flexible diplomacy that could be used to realize all Arab interests and the interest of other parties in any case.

\section{Conclusion}

It is clear from previous studies that there is a general agreement that traditional diplomacy with its various patterns in general and crises management diplomacy in particular is vulnerable to change in concepts and functions. In addition, crises management diplomacy is a new tool for international life in times of peace and war to solve problems and crises peacefully. The importance of previous studies stems from the fact that they help to understand the extent and capacity of crises management diplomacy. It means that developed countries have greater control over international relations and that developing countries have greater participation for safeguarding the rights of nations and productive interaction through dialogue and peaceful coexistence.

The literature on the role of diplomacy in the management of international crises contributed to the production of a great deal of theoretical and analytical foundations for the axes of the study. For example, the literature demonstrated the concept, patterns, types and management of diplomacy, namely crises management diplomacy and stages of diplomatic activity, and then the analysis of such activity and showing policies and methods adopted in this regard. Previous literature also dealt with experiences of Kuwaiti foreign policy making by diplomatic tool on the one hand and crisis management diplomacy on the other, as well as the analysis of the nature of relationship between them and ways of its development at the two regional and international levels.

\section{References}

Abdel Wahad, D. A. (2003). The Impact of the Gulf Crisis on Egyptian National Security (Unpublished doctorate dissertation). Cairo: Faculty of Economics and Political Science. 
Abdul Kader, A. A. (2011). The United States and the Crises of Nuclear Proliferation: The Iranian Case 2009-2011. Abu Dhabi: Emirates Center for Strategic Studies and Research.

Abu Arshid, O. (2014). The Ukrainian Crisis According to the American Approach: Restoration the Cold War again. Doha: Arab Center for Research and Policy Studies.

Ahmed, H. B. (2005). International Crisis Management. Cairo: Al-Ahram Center for Political and strategic studies.

Al-Azmi, H. F. (2014). Kuwaiti Foreign Policy towards the Gulf Countries from 1991 to 2012 (Unpublished master thesis). Cairo: Faculty of Economics and Political Science.

Al-Bashir, F. S. (2010). The Role of Diplomacy in the Peaceful Settlement of Disputes: An Applied Study of Kuwaiti Diplomacy 1990-2008 (Unpublished master thesis). Cairo: Faculty of Economics and Political Science.

Al-Batoul, A. M. (2009). Yemeni Diplomacy in the United Nations: A Case Study of Voting Behavior in General Assembly 1990-2003 (Unpublished doctorate dissertation). Cairo: Faculty of Economics and Political Science.

Al-Beheiry, W. A. (2009). The Role of Negotiations in International Crises Management: A Theoretical Study with Application to the Iranian Nuclear Crisis (Unpublished doctorate dissertation). Cairo: Faculty of Economics and Political Science.

Al-Futtaisi, H. B. (2018). Obstacles to Diplomacy and International Crises management. Retrieved from http://www.ahewar.org/debat/show.art.asp?aid=90401

Al-Hajj, B. M. (2007). The Evolution of the Palestinian Diplomatic Establishment from 1994 to 2004 (Unpublished mater thesis). Cairo: Institute of Arab Research and Studies.

Al-Khalidi, S. B. (2012). The State of Kuwait and International Agreements on Human Rights (Unpublished doctorate dissertation). Cairo: Faculty of Economics and Political Science.

Al-Mansour, M. A. (2013). The Role of the Economic Tool in Kuwait Foreign Policy: A Case Study of the Kuwaiti Fund for Arab Economic Development 1990-2011 (Unpublished master thesis). Cairo: Institute of Arab Research and Studies.

Al-Motairi, N. R., \& Zaki, A. (2013). Globalization and its Impact on Economics Diplomacy: An Empirical Study of Kuwait. IOSR journal of Business \& Management, 15(1). https://doi.org/10.9790/487X-1515459

Al-Muzain, I. A. (2009). The Impact of Regional and International Variables on Kuwaiti National Security: A Case Study from 1990 to 2009 (Unpublished Master Thesis). Alexandria: Alexandria of University.

Al-Naqi, Z. M. (2010). The Political Dimension in Kuwaiti Foreign Policy 1991-2006 (Unpublished master thesis). Cairo: Faculty of Economics and Political Science.

Al-Tammer, A. M. (2015). US Policy and International Crises Management: Iran, Iraq, Syria and Lebanon as Models. Beirut: Arab Center for Research and Policy Studies.

Alawi, M. (1987). Defining the Phenomenon of the International Crisis. Arab Strategic Thought J., 19, 159-160.

Alkenaee, M. (2011). The Boundary Dispute between Kuwait and Iraq Has it Subsided. Published master thesis. Beirut: School of Arts and Sciences, Lebanese American University.

Ameen, N. A. (2010). The Occupation of Iraq and International Responsibility of the United Nations (2003-2008) (Unpublished master thesis). Cairo: Faculty of Economics and Political Science.

Amiri, R. E., \& Soltani, F. (2011). Iraqi Invasion of Kuwaiti as Turing Point in Iran-Saudi Relationship. Journal of Politics and Law, 4(1). https://doi.org/10.5539/jpl.v4n1p188

Behgat, G. (2011). Kuwait Program on Development, Governance and Globalization in the Gulf States Sovereign Wealth Fund in the Gulf: An Assessment. London: LSE Global Governance.

Bellis, J., \& Smith, S. (2004). Globalization of Global Policy (Gulf Center for Research, Trans.). Dubai: Gulf Center for Research.

Brzeziniski, Z. (2012). Strategic Vision: America and Crises of Global Power. New York, NY: Basic Books.

Clayton, B. C. (2015). Market Madness: A Century of Oil Panics, Crises and Crashes. New York, NY: Oxford University Press.

Emara, M. H. (2014). The Role of Palestinian Diplomacy in Managing the Health Crisis during the Siege of 
Gaza Governorates (2006-2016) (Unpublished master thesis). Gaza: Al-Aqsa University. Retrieved from http://mpa.edu.ps/uploads/120110296.pdf

Fawzi, H. I. (2010). Public Diplomacy as a Tool for US Foreign Policy under President George W. Bush 2000-2008 (Unpublished master thesis). Cairo: Faculty of Economics and Political Science.

Frankel, J. (1976). Makers of Decisions and Crisis. New York, NY: Prager Publish ER, INC.

Haijala, A. M. (2000). Diplomacy of Great Powers under the International Regime towards the Arab World. Abu Dhabi: Emirates Center for Strategic Studies and Research.

Hermann, C. F. (1969). International Crisis as a Situational variable. In J. N. Rosenau (Ed.), International Political Foreign Policy: A Reader in Research and Theory. New York, NY: The Free Press.

Hocking, B., \& Melissen, J. (2015). Diplomacy in the Digital Age, Clingendaal Report. Netherlands: Netherlands Institute of International Relations.

Huwaidi, A. (1993). Crisis Management under Elusive World System. Al-Siyassa Al-Dawliya J., (112), 177-178.

Klavins, D. (2011). Understanding the Essence of Modern Diplomacy. The ICD Annual Academic Conference Diplomacy 2011: Cultural Diplomacy and International Relations, New Actors Initiatives, New Targets, Berlin, 15-18 December 2011.

Kupchan, C. A. (2010). How Enemies become Friends: The Sources of Stable Peace. New Jersey: Princeton University. https://doi.org/10.2307/j.ctt7s28g

Matwiczak, K. (2010). Public Diplomacy Model for the Assessment of Performance. A Report to the U.S. Advisory Commission on Public Diplomacy. Texas: The LBJ School of Public Affairs.

Mikled, I. S. (2013). Foreign Policy: Theoretical Origins and Political Applications. The Academic Library.

Moons, S. (2012). What are the Effects of Economic Diplomacy on the Margins of Trade? International Journal of Diplomacy and Economy, 1(2). https://doi.org/10.1504/IJDIPE.2012.051680

Mukhtar, A. (1992). Negotiations and Crises Management. Al-Siyassa Al-Dawliya Journal, (107), 283-284.

Nazir, M. (2010). Foreign Policy Crises Management: A Theoretical and Analytical Approach. Urban Dialogue site, the issue of 3219. Retrieved from http://www.ahewar.org/debat/show.art.asp?aid=238704

Nye, J. S. (2004). Soft Power and American Foreign Policy. Political Science Quarterly Journal, 119(2), 255-262. https://doi.org/10.2307/20202345

Pollock, D. (2007). Kuwait: Keystone of U.S. Gulf Policy. Policy Focus\# 76. Washington, DC: The Washington Institute for Near East Policy. Retrieved from www.mafhoum.com/press10/310p6.pdf

Selim, M. E. (1988). Analyzing Foreign Policy. Cairo: Dar Al-Ameen for Publishing.

Selim, M. E. (2002). The Evolution of International Politics in the Two Nineteenth and Twentieth Centuries. Cairo: Center for Political Research and Studies.

Smeitz, D. (2012). Foreign Policy in the New Millennium: Results of the 2012 Chicago Council Survey of American Public Opinion and U.S. Foreign Policy. Chicago, Il: The Chicago Council on Global Affairs.

Snyder, C. H. (1976). Conflict and Crisis in International System. In R. Thompson (Ed.), Beyond World Politics. New York, NY: The Free Press.

Snyder, I. G. (1972). Crisis Management. In C. F. Herman (Ed.), International Crisis. New York: The Free Press.

Suliman, K. A. (2011). The International Crisis and the International System: A Study in the Relationship between Strategic Crises Management and the Structure of the International System. Doha: Arab Center for Research and Policy Studies.

Zaharna, R. S. (2003). The Unintended Consequences of Crisis Public Diplomacy: American Public in the Arab World. Policy Brief, $8(2)$ Retrieved http://american.edu/soc/faculty/upload/zahrana-crisis-public-diplomacy-03.pdf

\section{Copyrights}

Copyright for this article is retained by the author(s), with first publication rights granted to the journal.

This is an open-access article distributed under the terms and conditions of the Creative Commons Attribution license (http://creativecommons.org/licenses/by/4.0/). 